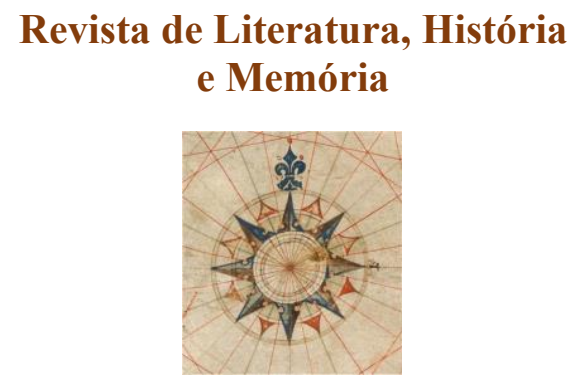

Seção: Pesquisa em Letras no contexto Latino-americano e Literatura, Ensino e Cultura

ISSN 1983-1498

VOL. 17 - No 29 - 2021

U N I O E S T E / CA S C A V E L - p. 371-400

\title{
INVISIBILIDADE, PARASITISMO E CANIBALISMO: EMBATES DA HEROÍNA ROSÉLIE EM HISTOIRE DE LA FEMME CANNIBALE, DE MARYSE CONDÉ
}

invisibility, parasitism and cannibalism: embapts of the heroine Rosélie in Histoire de la femme cannibale, by Maryse Condé

Vanessa Massoni da Rocha ${ }^{1}$

RESUMO: Este artigo analisa o romance Histoire de la femme cannibale, de 2003, da escritora do arquipélago caribenho de Guadalupe Maryse Condé a partir das premissas do feminismo negro (Djamila Ribeiro) e do feminismo decolonial (Françoise Vergès). Trata-se de observar como a protagonista do romance, Rosélie, tem a trajetória transpassada pela tríade invisibilidade, parasitismo e canibalismo. De origem antilhana, a personagem possui um casamento inter-racial e experiencia um exílio africano, na Cidade do Cabo pós-apartheid. Estas condições lhe impõem a invisibilidade social, a xenofobia e a segregação que ainda vigoram no país sul africano. Diante do olhar excludente e depreciativo do outro, Rosélie desenvolve uma dinâmica de sobrevivência baseada em 'parasitar' o marido, um professor branco de origem irlandesa especialista em literatura. A partir de sua verve de pintora, a personagem aposta nas metáforas do canibalismo - e sua interface com o movimento antropofágico brasileiro - para superar o trauma de viuvez inesperada que lhe força a assumir o protagonismo de sua vida. Análises de entrevistas de Condé e de textos de Evaristo, Adichie, Benjamin, Berry, Andrade, Tremblay, Sourieau, Viala, Migraine-Georges, Glissant, Sch $œ$ lcher e Figueiredo, entre outros, nos permitirão observar a composição de personagens que aludem à autorrepresentação feminina na contemporaneidade.

PALAVRAS-CHAVE: Invisibilidade; Parasitismo; Canibalismo; Autorrepresentação feminina; Literatura antilhana; Maryse Condé;

ABSTRACT: This article analyzes the novel Histoire de la femme cannibale, 2003, by the writer of the Caribbean archipelago of Guadalupe Maryse Condé from the premises of black feminism (Djamila Ribeiro) and decolonial feminism (Françoise Vergès). It is about observing how the protagonist of the novel, Rosélie, has a trajectory transposed by the triad of invisibility, parasitism and cannibalism. Of Caribbean origin, the character has a mixed marriage and experiences an African exile in postapartheid Cape Town. These conditions impose on him the social invisibility, xenophobia and segregation that still exist in the South African country. Faced with the exclusionary and derogatory gaze of the other, Rosélie develops a survival dynamic based on 'parasitizing' her husband, a white teacher of Irish origin specializing in literature. From her painterly verve, the character bets on the metaphors of cannibalism - and its interface with the Brazilian anthropophagic movement - to overcome the trauma of unexpected widowhood that forces her to take the leading role of her life. Analysis of interviews by Condé and texts by Evaristo, Adichie, Benjamin, Berry, Andrade, Tremblay, Sourieau, Viala, Migraine-Georges, Glissant, Schœlcher and Figueiredo, among others, will allow us to observe the composition of characters that allude to female self-representation in contemporary times.

KEYWORDS: Invisibility; Parasitism; Cannibalism; Female self-representation; Caribbean literature; Maryse Condé;

\footnotetext{
${ }^{1}$ Doutora em Estudos de Literatura pela Universidade Federal Fluminense (UFF). Professora de Língua francesa e de Literaturas francófonas nos programas de Graduação em Letras e de Pós-Graduação Lato sensu na Universidade Federal Fluminense (UFF).
} 
No desejo, há mais canibalismo que amor. Um canibalismo contrário que pica o corpo, até se convidar a uma boca que está encarregada de comê-lo. James Noël (AMARAL, 2020, p. 67).

\section{MARYSE CONDÉ: APONTAMENTOS BIOGRÁFICOS E DECOLONIAIS}

A escritora guadalupense Maryse Condé (1937) publica o romance Histoire de la femme cannibale [História da mulher canibal] em 2003, quando estava prestes a completar uma década como professora emérita na Universidade de Columbia em Nova York, nos Estados Unidos, onde havia fundado e dirigia o Departamento de Estudos Francófonos. No mesmo ano, Condé foi laureada com o Prêmio Metropolis bleu pelo conjunto da sua obra. Iniciou suas atividades em torno do livro, aos 29 anos, e produz, de maneira regular, por mais de seis décadas. Nos últimos tempos, a saúde debilitada dificultou o processo de produção literária. O romance Le fabuleux et triste destin d'Ivan et Ivana [O fabuloso destino de Ivan e de Ivana], de 2017, precisou ser ditado ao marido. O fato, a despeito da fragilização da doença, retoma a figura do contador de histórias que povoa o imaginário crioulo. Condé se desloca em cadeira de rodas e perdeu parte da visão e do movimento das mãos, o que não a impede de se dedicar atualmente à concepção de um novo romance, com o título provisório de L'Évangile de Pascal. "Maryse Condé, escrever e não ceder"2 (2019, s/p), eis o título preciso da entrevista concedida por Condé a Laurent Larcher para o periódico La Croix, em setembro de 2019. Nela, Condé antecipa parte da intriga do livro: "a história de um órfão que terá uma vida exemplar"’3. Condé e o marido vivem nos dias de hoje na cidade de Gordes, no Maciço de Luberon, sul da França.

Considerada a grande matriarca da literatura empreendida no arquipélago caribenho de Guadalupe, Maryse nos legou uma obra contundente e extensa formada por mais de cinquenta produções. Para além da importância do gênero romanesco em sua verve literária, ela também se dedicou ao conto, ao ensaio, ao teatro (gênero de estreia no circuito literário), a obras dedicadas ao público infantojuvenil, à tradução e à organização de antologias. A quantidade de prêmios que lhe foi atribuída se revela igualmente superlativa, mais de duas dezenas, sendo os mais recentes até o momento o New Academy Prize (Prêmio Nobel alternativo), em 2018,

\footnotetext{
${ }^{2}$ São de minha autoria a tradução para o português de entrevistas e de textos teóricos e literários referenciados em francês e em inglês. "Maryse Condé, écrire et ne rien céder"

3 "c'est l'histoire d'un orphelin qui aura une vie exemplaire"
} 
e a Grande Cruz da Ordem Nacional do Mérito da França, em 2019. Não restam dúvidas de que Maryse Condé se tornou figura central no panteão guadalupense, tendo se tornado o maior expoente literário do arquipélago e importante representante da literatura caribenha no cenário internacional. Dentre as distinções recebidas, seu nome figura no prêmio literário Fetkann! Maryse Condé e batiza uma rua em Port-Louis, em Grande-Terre, Guadalupe.

Maryse obtem seu doutorado em Letras na Universidade de Sorbonne, a mais prestigiosa de Paris. Mora em Guadalupe, na França, na Costa do Marfim, na Guiné (após o casamento em 1959 com o ator guineano Mamadou Condé, de quem adotou o sobrenome artístico e com quem teve quatro filhos), em Gana (de onde foi extraditada em 1966 sob suspeita de espionagem), em Londres, no Senegal (onde conheceu o segundo marido) e nos Estados Unidos. Após seu divórcio, ela se casa em 1981 com o britânico Richard Philcox, professor de língua inglesa e tradutor ${ }^{4}$ de Fanon e das obras de Condé para o inglês. A Richard, companheiro de longa data, Maryse dedicou inúmeros livros, dentre os quais Histoire de la femme cannibale (2003), Mets et merveilles [Pratos e maravilhas] (2015), no qual cartografa a vida do casal e o apreço pela gastronomia, e Le fabuleux et triste destin d'Ivan et Ivana, de 2017. O tema tabu do casamento inter-racial que acompanhou a biografia do casal se faz presente em diversas obras, como Histoire de la femme cannibale, na qual uma série de questionamentos tira o véu da inocência e revela que o incômodo gerado pelo casamento inter-racial desvela outro desconforto, o do preconceito racial, como ilustra o trecho a seguir:

Por que só se leva em conta o elemento biológico? Não é um casamento misto o casamento de um espanhol e uma belga? De um alemão com uma italiana? De um tcheco com uma romena? De um americano e de uma francesa? E, no final de tudo, todos os casais não são mistos? ${ }^{5}$ (2012, p.7677).

A obra de Condé foi traduzida para dezenas de línguas, dentre elas o português. O acervo nesta língua, deveras tímido, conta com apenas duas obras até o presente momento:

\footnotetext{
${ }^{4}$ Em entrevista à Marjory Adenet-Louvet, em 2007, Richard Philcox revela o início de sua relação com Maryse Condé: "Comecei a traduzir Maryse Condé no início dos anos 70 após a publicação de seu primeiro romance Heremakhonon. Fui tradutor técnico da Kodak-Pathé em Paris, mas nossas viagens aos EUA já antecipavam outros horizontes e traduções para o inglês. Nós nos conhecemos muito antes da carreira de escritora de Maryse, então minha tradução do romance Heremakhonon foi mais um trabalho de amor. Eu conheci a mulher muito antes de conhecer a escritora. Sendo do idioma inglês, era normal que eu desejasse que o trabalho dele chegasse a um público de língua inglesa" (2007, s/p)

5 "Pourquoi ne prend-on en compte que l'élément biologique? N'est-ce pas un mariage mixte que celui d'un Espagnol et d'une Belge? d'un Allemand et d'une Italienne? D'un Tchèque et d'une Roumaine? D'un Américain et d'une Française? Et, puis, tous les couples ne sont-ils pas mixtes ?"
} 
Corações migrantes (2002) e Eu, Tituba, Feiticeira negra de Salém (1997 para a primeira edição pela editora Rocco e 2019 pela editora Rosa dos $\operatorname{Ventos}^{6}$ ). A escritora brasileira Conceição Evaristo, em prefácio para a reedição de 2019 de Eu Tituba..., defende que Condé "sabe lidar com a alquimia das palavras" e "tem as fórmulas, as poções mágicas da escrita" (2019, p.13). Evaristo retoma a pesquisadora Ana Maria Roeber ao salientar o fato de que "a narrativa traz como protagonista uma mulher. E é nela que a escritora concentra o seu foco, desejando the conferir uma heroicidade" $(2019$, p.8). Por fim, a escritora brasileira, laureada com o prêmio Jabuti de 2015, enfatiza que "Maryse Condé, com uma espécie poética da dor (...) magistralmente constrói um relato mesclando história e ficção. E no vazio da história, a ficção, o invento, entra para suprir a ausência de informação" (2019, p. 12). Nesses trechos, algumas informações chamam nossa atenção. De início, o reconhecimento do heroísmo feminino nas obras da caribenha. Em seguida, Evaristo faz alusão ao binômio história e ficção que caracteriza tanto o conjunto da obra de Condé quando o de si mesma. Inscritas sob a premissa pós-colonial, estas ficções confrontam e fragilizam a crônica oficial da empreitada colonial, se recusam a acatar os solilóquios impositivos e perigosos da "história única" (ADICHIE, 2019) e se inscrevem na perspectiva de reescrita crítica capaz, como preconizava Walter Benjamin, de escovar a história a contrapelo (apud LÖWY, 2011, p.21).

É mister ressaltar que a reedição de Maryse Condé em 2019 no Brasil se inscreve no profícuo florescimento da literatura afro-brasileira, notadamente de expressão feminina, a partir das perspectivas do feminismo negro (Djamila Ribeiro) e do feminismo decolonial (Françoise Vergès). O prefácio redigido por Conceição estreita as relações históricas e literárias que aproximam o arquipélago antilhano e o Brasil, espaços que compartilham as dores, os lutos, as violências e as sequelas (SCHCELCHER, 2008, p.191) do jugo colonial, da diáspora africana e da escravização impetradas pelas potências europeias a partir do século XV nas Américas. Como define o intelectual martinicano Édouard Glissant, o Caribe e o Brasil integram a chamada "Neo-América" (GLISSANT, 1996, p.59), área marcada pela imprevisibilidade e pelo fenômeno da alteridade. Sob esta perspectiva, as vozes de Condé e Evaristo se somam às vozes cada vez mais numerosas dos cenários literários antilhanos e brasileiro, vozes estas que se propõem a passar a limpo histórias de dominação, buscando pulverizar versões maciçamente entoadas para dar a ver novos paradigmas e novas histórias comprometidos com as premissas antirracistas, anti-imperialistas, antissexistas e verdadeiramente decoloniais.

\footnotetext{
${ }^{6} \mathrm{Na}$ edição mais recente, de 2019, o título Eu, Tituba: Feiticeira negra de Salém passou a ser Eu, Tituba: Bruxa negra de Salém.
} 
Como defende a filósofa brasileira Djamila Ribeiro, busca-se quebrar "a máscara do silêncio" (2018, p.26), "pensar projetos democráticos” (2018, p.7) que alargam o conceito de humanidade (2018, p.27) e lutar para que "diferenças não signifiquem desigualdades" (2018, p.27). O mote que se imprime neste novo paradigma pode ser resumido pela sentença: "Quero ser protagonista da minha história, e não personagem caricato para uma sociedade racista" (2018, p.61). Busca-se à luz da politóloga francesa Françoise Vergès, oriunda da Ilha da Reunião, exercer "a reapropriação científica e filosófica que revisa a narrativa europeia do mundo" (2020, p.39) a partir de uma "análise multidimensional" (2020, p.47). O intuito consiste em se voltar "para os problemas gerados pelas relações coloniais (em que se inserem a escravidão e seus efeitos deletérios) e também para as imaginações emancipatórias elaboradas neste mundo em que a questão da raça se impôs de forma visceral (RIOS, 2020, p.8).

Sob este ponto de vista, no romance Histoire de la femme cannibale há a notícia da criação da Associação de defesa das negras (CONDÉ, 2012, p.69) e a declaração de que "neste planeta, não há uma única mulher negra que um dia ou outro não tenha sido duplamente humilhada por causa de seu gênero e de sua cor"7 (CONDÉ, 2012, p. 70). Maryse Condé explica em entrevista que "em alguma medida os escritores já são pós-coloniais, já que sua liberdade é escolher, compor sua própria linguagem. Se tentarmos tirar essa liberdade, mesmo com intenções válidas, é uma grave ferida que lhe infligimos”8 (ALI-BENALI, 2009, p. 15). Aprofundando a discussão, a autora brinca com o ethos de seu universo literário ao afirmar que "alguns dizem que um escritor sempre escreve o mesmo livro. É exagerado. Ainda assim, existe através de um trabalho perguntas que surgem repetidas vezes porque escritores não encontram uma resposta"9 (ALI-BENALI, 2009, p.16). Logo, Condé cunha o leitmotiv de sua escrita: a busca de respostas envolvendo temáticas de eleição, tais como "Guadalupe, a condição do negro em solo branco, negritude, descolonização, escravidão, África, identidade, mulher e liberdade, escrita, livros, solidão, reconhecimento, racismo"10 (LARCHER, 2019).

\footnotetext{
7 “sur cette planète, il n'est pas de femme noire qui un jour ou l'autre n'ait été doublement humiliée à cause de son sexe et de sa couleur"

8 “d'une certaine manière, les écrivains sont déjà postcoloniaux puisque leur liberté est celle de choisir, de composer leur propre langage. Si on essaie de leur enlever cette liberté, même avec des intentions valables, c'est une grave blessure qu'on leur inflige"

9 “Certains disent qu'un écrivain écrit toujours le même livre. C'est exagéré. N'empêche qu'il y a, à travers une œuvre, des questions qui reviennent encore et encore parce que les écrivains n'y trouvent pas de réponse"

10 "la Guadeloupe, la condition du Noir en terre blanche, la négritude, la décolonisation, l'esclavage, l'Afrique, l'identité, la femme et la liberté, l'écriture, les livres, la solitude, la reconnaissance, le racisme"
} 


\section{HISTOIRE DE LA FEMME CANNIBALE: CAMINHOS DA INVISIBILIDADE E DO PARASITISMO}

O romance Histoire de la femme cannibale acompanha a vida de Rosélie Thibaudin, mulher negra de origem guadalupense, que acabou de se tornar viúva após o assassinato brutal do marido Stephen Stewart, um irlandês, branco, intelectual e professor universitário de literatura. $\mathrm{O}$ casal viveu junto por 20 anos e o falecimento do companheiro se torna um grande divisor de águas para Rosélie. Acostumada a ser coadjuvante de sua própria vida, a personagem enfrenta o desafio de exercer o protagonismo que se apresenta em decorrência do desenlace matrimonial. Definida como "desertificada" 11 (CONDÉ, 2012, p.37), sem amigas (CONDÉ, 2012, p. 63), alimentando traumas ligados ao abandono afetivo, profundamente solitária e desempregada, ela encontra interlocução junto à empregada Dido. A mestiça sulafricana, cuja família é originária de Madagascar, sugere que a patroa se torne médium e massagista, o que lhe assegura retorno financeiro. O fato se torna curioso, pois Rosélie flerta com o isolamento e com uma vida de autômata, o que não parece preencher os pré-requisitos básicos para se ocupar da "cura de casos reconhecidamente incuráveis"12 (CONDÉ, 2012, p. 18). Ela contribui para que os pacientes encontrem a cura e a paz que escapam a ela mesma no quotidiano. O romance cita vinte pacientes e reproduz a ficha de consulta de pelo menos seis deles. Em sua maioria, são migrantes que sofrem as agruras da diáspora e do exílio, da nãointegração, da xenofobia e dos preconceitos raciais.

A presença de Dido e sua insistência em chamar Rosélie para a vida, tornando-se um esteio fundamental em meio a tanta precariedade, podem ser melhor compreendidas através desta pista de leitura revelada por Maryse Condé:

Em uma sociedade como o Caribe, quem sabe mais do que os empregados sobre a construção da sociedade, os detalhes da sociedade? Ninguém nunca lhes pede sua opinião, mas eles estão lá, eles são testemunhas; eles são os únicos que veem, eles são os únicos que organizam tudo. Simplesmente, uma história caribenha não poderia realmente ser contada sem referência aos empregados. Não se esqueça que, afinal, como uma pessoa negra, eu descendo dos escravos, e os escravos estavam sempre em silêncio, forçados a ficar em silêncio. Eles sabiam que eram os verdadeiros mestres da ilha. Era uma maneira de dar voz ao meu povo, que nunca recebeu vozes antes ${ }^{13}$

\footnotetext{
11 "désertée"

12 "guérison de cas reconnus incurables"

13 "in a society like the Caribbean, who knows more than the servants about the construction of society, the details of the society? Nobody ever asks them their opinion, but they are there, they are witnesses; they are the ones who see, they are the ones who arrange everything. Simply, a Caribbean story could not really be told without reference to servants. Don't forget that, after all, as a black person, I descend from the slaves, and the slaves were always silent, forced to be silent. They knew they were the real masters of the island. It was a way of
} 
(WOLFF, 1999).

Dido perdeu o filho para a AIDS e carrega consigo dores extremas que não a impedem de zelar pela patroa, por quem desenvolve um misto de pena e de amizade. Revelações finais da obra, acerca da sexualidade do marido falecido de Rosélie, ocorrem justamente em conversa com Dido. É ela quem exerce a função de cicerone para a patroa em passeios por Lievland, incursões que ajudam Rosélie a superar a depressão da viuvez. Mais uma vez, é ela a primeira a desconfiar das intenções de Faustin, primeiro namorado pós-viuvez de Rosélie, e a ela cabe o papel de cupido capaz de estreitar as relações entre a chefe e o inspetor de polícia que desvenda o assassinato de Stephen.

Do ponto de vista formal, o romance se organiza em torno de vinte capítulos e alterna a narração, em primeira pessoa, feita por Rosélie, e também a narração em terceira pessoa feita por um narrador desconhecido. A intriga sobrepõe passado e presente, prescindindo de datas e de sequências lineares. O texto aposta em flashbacks e se tece em torno de rememorações da infância, da vida amorosa de Rosélie e da vida do casal que se somam ao inquérito policial da morte de Stephen e seus desdobramentos, bem como a nova rotina da protagonista. Em muitos momentos, o leitor tem dificuldades para se localizar em um emaranhado de tempos cronológicos e numa profusão de personagens. A desordem temporal e o tom - nervoso, por vezes, do texto contribuem para a pintura do descompasso, tanto da Cidade do Cabo quando de Rosélie, que se aproximam num jogo de espelhamento por estarem em busca de si mesmas e da elaboração identitária em meio ao caos. A cena inicial da obra descreve a chegada do trem com trabalhadores do antigo campo de concentração, transformado em atração turística internacional. Há sirenes, helicópteros, freios de ônibus, seguidas da descrição:

a noite da Cidade do Cabo transbordava de todos os tipos de fedores e de podridões. Era um pesadelo do qual a cidade saía sem sangue, seus canais arando a bile e o pus, a cabeleira de nêspera e de pinheiros marítimos enrijecidos pelo medo ${ }^{14}$ (CONDÉ, 2012, p.12).

Logo em seguida, Rosélie é apresentada:

Rosélie se senta sobre a cama que, há três meses, ocupava sozinha, em

giving voice to my people, who were never given voices before"

14 "la nuit du Cap débordait de toutes qualités de puanteurs et de pourritures. C'était un cauchemar dont la ville sortait exsangue, ses dalots charroyant la bile et la sanie, sa chevelure de néfliers et de pins maritimes raidie d'effroi" 
posição fetal, o nariz colado no muro porque o vazio atrás de suas costas a aterrorizava (...) Não durmo mais. (...) Eu mordo meus lábios: eles sangram. Gemo. Me deito e gemo ${ }^{15}$ (CONDÉ, 2012, p.12).

Assim, a cidade e Rosélie compartilham as dores, a putrefação, a égide do pesadelo neste presente assolador e cruel, que dói, sangra, expõe as vísceras, flerta com a doença, a loucura e a morte. São a viúva e a cidade personagens que se equilibram em um tênue fio, na tentativa de evitar a queda mortal.

Rosélie e o marido tinham vivido em N'Dossou e em Nova York (durante 7 anos) antes de adotarem, por razões afetivas e profissionais dele, a Cidade do Cabo, capital da África do Sul. Rosélie era contra o desejo de marido e não hesitava em demonstrar sua contrariedade de viver nesse "país execrável"16 (CONDÉ, 2012, p. 120). À época, a cidade vivia os frágeis e conturbados momentos pós-apartheid e estava mergulhada em episódios de segregação, de racismo, de violência generalizada e de turismo histórico pelos traços do líder Nelson Mandela. Rosélie vivia apartada da cidade, de que não gostava, mas de onde não conseguia partir. Ao ser questionada acerca da identidade de seu país natal, responde

Minha casa? Se eu soubesse onde é. Sim, o acaso me fez nascer na Guadalupe. Mas, na minha família, ninguém quer saber de mim. Além disso, vivi na França. Um homem me levou e me despejou em um país da África. De lá, outro me levou aos Estados Unidos, depois me levou para a África para lá me abandonar, ele também, na Cidade do Cabo, Ah, esqueci de dizer, vivi também no Japão. (...) Meu único país é Stephen. Onde ele estiver, eu fico $^{17}$ (CONDÉ, 2012, p.43).

Este trecho, um dos mais reproduzidos e conhecidos da obra, nos remete à confissão de Maryse Condé: "me sinto próxima de todos os escritores que questionam as noções de origem, de lugar de residência, de identidade coletiva"18 (ALI-BENALI, 2009, p. 23). Estas considerações reverberam na indagação de Eurídice Figueiredo: "qual é o país natal para pessoas que não se sentem nativas de/em nenhum lugar?” (1998, p. 132). A pesquisadora afirma que a temática "do exílio e do sentir-se estrangeiro onde quer que se encontre, do nomadismo e da busca de uma identidade/legitimidade associada a um país natal perpassa

\footnotetext{
15 "Rosélie s'assit sur le lit que, depuis trois mois, elle occupait seule, roulée en position de foetus, le nez collé contre la cloison parce que le vide sur son dos la terrifiait. (...) Je ne dors plus. (...) Je mords mes lèvres: elles saignent. Je geins. Je gis et je geins"

16 "pays exécrable"

17 "Chez moi? Si seulement je savais où c'est. Oui, le hasard m'a fait naître à la Guadeloupe. Mais, dans ma famille, personne ne veut de moi. À part cela, j'ai vécu en France. Un homme m'a emmenée puis larguée dans un pays d'Afrique. De là, un autre m'a emmenée aux États-Unis, puis ramenée en Afrique pour m'y larguer à présent, lui aussi au Cap. Ah, j'oubliais, j'ai aussi vécu au Japon. (...) mon seul pays, c'était Stephen. Là où il est, je reste"
} 
toda a obra de Maryse Condé" (1998, p.131-132).

Destaca-se neste fragmento literário a maneira como Rosélie constrói seu discurso, atribuindo protagonismo aos homens que decidem partir e levá-la, o que acaba por corroborar sua passividade e inércia, mulher que é conduzida pelos homens como objeto pertencente a seus enxovais. Rosélie se descreve como uma mulher esvaziada de si mesmo, impedida de caminhar com seus próprios passos e sempre escondida por detrás de outro alguém, seja ele algum namorado, o marido ou até a empregada e fiel escudeira Dido. O sentimento amoroso ganha em Histoire de la femme cannibale contornos de dependência afetiva, cativeiro amoroso, "gaiola conjugal"19 (VIALA, 2010, p.134) e renúncia à individualidade. Ela erige o marido ao posto de país a ser habitado para mascarar sua impossibilidade de habitar plenamente um lugar e de se identificar a um lar, a um espaço de acolhimento. Neste ponto, não parece anódino o fato de a personagem sempre ter se deixado fascinar por turistas (CONDÉ, 2012, p.109), seres que por definição se deslocam e frequentam, de modo efêmero, os lugares. Rosélie se mostra arredia às ancoragens, às definições geográficas, à necessidade de se associar por completo a uma história, a uma tradição, a uma identidade. O personagem Faustin lhe disse certa vez: "você é como os nômades. Teu teto é o céu acima da tua cabeça" 20 (CONDÉ, 2012, p. 293).

Por certo, "as obras de Condé exprimem o contato, o sincronismo e os cruzamentos entre culturas, assegurando a conscientização que ajuda a construir o interesse pelo seu próprio povo e compreender a sua própria história tão marcada por imigrações e hibridismos" (CAVAGNOLI, 2011, p.151). Sob este ponto de vista, a personagem Rosélie se aproxima sobremaneira da escritora Maryse Condé e sua conhecida errância: "a escritora Maryse Condé, um verdadeiro produto da diáspora caribenha, vem a ser um dos fiéis exemplos de exílio, expatriação e ambivalência no esquema de quadrangulação (Caribe-Europa-ÁfricaEUA)" (CAVAGNOLI, 2011, p.147).

No que concerne às dificuldades vislumbradas pelas mulheres, Condé discorre a propósito de suas personagens, notadamente de Thécla, de La vie Scélérate (1987), Véronica, de Hérémakhonon (1988) e de Rosélie, de Histoire de la femme cannibale (2003):

Para nós, mulheres, é sempre mais difícil. Como conseguir nos impor em nossas sociedades? Primeiro como chegar a conhecer a nós mesmas, saber quem somos, o que queremos. Isto é simbólico, mas Thécla sempre passa por homens para conseguir se realizar. Repito, todas as mulheres nos meus

\footnotetext{
19 "cage conjugale"

20 "tu es comme les nômades. Ton toit, c'est le ciel au-dessus de ta tête"
} 
livros, da Véronica (Hérémakhonon) até Rosélie, são incapazes de alcançar a autonomia. Eles precisam absolutamente de um homem para levá-las a um resultado. É claro que Thécla é vítima de sua condição de mulher ${ }^{21}$ (ALIBENALI, 2009, p. 18).

A representação feminina nas obras de Maryse Condé acolhe a opressão de mulheres tuteladas e/ou obliteradas por namorados, maridos e familiares. A autora traz à tona a dificuldade do livre-arbítrio, os receios e a dependência que fragilizam algumas de suas protagonistas. O panteão de personagens fortes, resistentes e poderosas como Tituba (Moi, Tituba, sorcière noire de Salem, 1986), Marie-Noëlle (Desirada, 1997) e Victoire (Victoire, des saveurs et des mots, 2006) se vê ladeado por um conjunto de mulheres em sofrimento que desconhecem a inteireza. Assim, Condé compõe um mosaico bastante rico das experiências femininas através de forças e fraquezas, vitórias e insucessos, lideranças e alijamentos, embates e onipotências. Em 1993, a escritora se atém às diferenças entre discursos femininos e masculinos:

O que elas expressam é muito diferente do que exprimem os homens. Não é uma reivindicação política, não é a consciência que leva à luta, também não é o feminismo ocidental. Parece que as mulheres estão interessadas em coisas que chamamos de intimistas e que de fato são problemas da sociedade. Elas falam muito sobre questões de cores, relacionamentos com homens e crianças. Elas falam mais disso do que grandes problemas como o racismo, exploração ou ideologia ${ }^{22}$ (PFAFF, 1993, p. 60).

É importante destacar que apesar de toda a precariedade e invisibilidade da personagem Rosélie, grande parte do romance ocorre por intermédio de uma narração em primeira pessoa, na qual a protagonista assume as rédeas do discurso e concebe os personagens a partir de sua perspectiva, seus filtros e desejos. Não deixa de ser, acreditamos, um procedimento de revanche contra a marginalidade ao qual se vê reduzida. Assim, ao forjar com palavras as versões capazes de definir seus interlocutores e seus relacionamentos, ela constrói um ritual de passagem que lhe suprime a pequenez de outrora. Nesse sentido, há um deslocamento da personagem ao longo da obra: trocar a invisibilidade do outro por um olhar

\footnotetext{
21 “Pour nous les femmes, c'est toujours plus dur. Comment arriver à nous imposer dans nos sociétés ? D'abord comment arriver à nous connaître, à savoir qui nous sommes, ce que nous voulons. C'est symbolique, mais Thécla passe toujours par des hommes pour arriver à se réaliser. Je le répète, toutes les femmes de mes livres, depuis Véronica (Hérémakhonon) jusqu'à Rosélie, sont incapables d'arriver à l'autonomie. Il leur faut absolument un homme pour les conduire à un résultat. Sûr, Thécla est aussi victime de sa condition de femme" 22 "Ce qu'elles expriment est très différent de ce qu'expriment les hommes. Ce n'est pas la revendication politique, ce n'est pas la prise de conscience qui débouche sur la lutte, ce n'est pas non plus le féminisme à l'occidentale. Il semble que les femmes s'intéressent à des choses qu'on appelle intimistes et qui, en fait, sont des problèmes de société"
} 
capaz de apreendê-lo. "Olhos oblíquos"23 (CONDÉ, 2012, p.12), como define o narrador, o que nos remete imediatamente à malícia perturbadora da personagem Capitu na obra Dom Casmurro (1899) de Machado de Assis. Com Dom Casmurro, Histoire de la femme cannibale compartilha a temática da suspeição da traição e seus desdobramentos. Na obra guadalupense, a traição ascende ao primeiro plano da narrativa na parte final da intriga, quando o inquérito policial desvenda casos extraconjugais homossexuais de Stephen.

$\mathrm{Na}$ Cidade do Cabo, a personagem Rosélie experimenta as agruras de um pósapartheid cujas feridas ainda se mostram abertas: "nunca ela tinha se sentido tão negada, excluída, relegada ao longe por causa de sua cor" ${ }^{4}$ (CONDÉ, 2012, p.50). "Ela tinha se tornado invisível. Triste escolha! Exclusão ou invisibilidade! Invisible woman!”25 (2012, p.50) Outras cenas demonstram que "era isso, a Cidade do Cabo! Esta hostilidade dos brancos envenenando o ar como um miasma. Esta impressão de um perigo que surge não se sabe de onde. (...) Nesse pedaço de terra só existiam tensões, ódio, desejo de vingança!"26 (CONDÉ, 2012, p.99-100). Desta forma, o romance continua a tecer a simbiose entre a cidade e Rosélie, cada uma se esmerando em negar, rasurar, ofuscar a outra. Morando no marido, e daí minimizando qualquer possibilidade de apreço com o exterior de sua casa, ela insiste em excluir a cidade e esta não hesita em apequenar a existência da mulher negra. Por sua vez, Stephen se definia como "apátrida" 27 (CONDÉ, 2012, p.55) e fugiu da Europa após o divórcio e os conflitos entre os progenitores. É Dido que se oferece como contraponto ao olhar indiferente de Rosélie para a cidade. A empregada mestiça comemora a possibilidade de frequentar espaços cujas portas se mantiveram, por muito tempo, fechadas, para ela, durante o regime segregacionista: "Não posso acreditar que é aqui que estou sentada, repetia. Quando era pequena, este lugar, como tantos outros, era proibido para nós! E eu sonhava com ele"28 (CONDÉ, 2012, p.109).

Em dado momento do romance, o personagem Raymond pondera que "o problema maior da África é que lá não tem opinião pública. (...) Por que não tem opinião pública? Porque as pessoas não têm força" ${ }^{29}$ (CONDÉ, 2012, p. 146). Eis um novo elemento neste

\footnotetext{
23 "yeux obliques"

24 "Jamais elle ne s'était sentie plus niée, exclue, reléguée au loin à cause de sa couleur"

25 "Elle était redevenue invisible. Triste choix! Exclusion ou invisibilité! Invisible woman"

26 'C'était cela, Le Cap! Cette hostilité des Blancs empoisonnant l'air comme un miasme. Cette impression d'un danger qui fondrait on ne sait d'où. (...) il n'y avait dans ce bout de terre que des tensions, de la haine, le désir de vengeance !"

27 "apatride"

28 “je ne peux pas croire que c’est là que je suis assise, répétait-elle. Quand j’étais petite, cet endroit-là, comme tant d'autres, nous était interdit ! Et j'en rêvais"

29 “'Le problème majeur de l'Afrique, c'est qu'il n'y a pas d'opinion publique. (...) Parce que les gens sont sans force"
} 
espelhamento entre a personagem e o espaço onde vive. Rosélie se define pela negação, pela recusa e pela impossibilidade. Vive sob o arrimo do 'não', como demonstram os trechos a seguir: "Nada. Não penso em nada. Não penso em nada porque não conheço nada. Não conheço nada de nada" (CONDÉ, 2012, p.62), "Eu vivo como parasita. Não possuo nem carreira. Nem fortuna. Nem bens materiais. Nem bens espirituais. Nem presente. Nem futuro"30 (CONDÉ, 2012, p. 68). A sequência nos remete à enumeração de privações elencadas pela pesquisadora Alice Cherki no préfacio da obra fanoniana Os condenados da terra (1961), na qual insiste sobre as consequências nefastas da empreitada colonial e de seus prolongamentos: "sem pátria, sem território, mas também sem domicílio, sem trabalho, sem documentos, sem direito a um espaço de fala" ${ }^{31}$ (2015, p. 15). O ímpeto da ausência evocado por Cherki, contudo, não se aplica à Rosélie, inscrita numa elite financeira. De fato, a personagem vive uma vida confortável, viaja, possui casa própria, tem uma empregada que se comporta como dama de companhia e conselheira, além de não trabalhar há vinte anos (é o falecimento do marido que torna necessária uma atividade remunerada). Sua postura coadjuvante não se explica em nada pelos bem materiais e pela rotina que mantém. A precariedade, a invisibilidade e o parasitismo espelham um mundo interior, definem uma mulher apartada da vida social e que sobrevive recolhida numa transparência que a alija das relações interpessoais.

Em outro momento, o narrador salienta que "Rosélie se privou de qualquer comentário, ela que se recusava a julgar, a condenar, a questionar"32 (CONDÉ, 2012, p. 91). Mais adiante, explicita-se que "como sempre, Stephen falava por dois" 33 (CONDÉ, 2012, p. 141) e "Faltava à Rosélie a energia para se defender" 34 (CONDÉ, 2012, p. 264). Ela mesma reconhece: "eu negava a verdade para não precisar decidir"35 (CONDÉ, 2012, p. 311). De fato, a personagem encerra uma "insegurança" 36 (CONDÉ, 2012, p.93) de quem se percebe acostumada a ser ferida, maltratada (CONDÉ, 2012, p. 92). Chegou a ser confundida com a empregada pelos amigos intelectuais do marido (CONDÉ, 2012, p.42) e é definida como alguém acostumada à invisibilidade (CONDÉ, 2012, p.137). Neste sentido, Rosélie encarna uma mulher desprovida de quereres, emudecida, obliterada e desabituada a conduzir sua

\footnotetext{
30 “Je vis en parasite. Je ne possède ni carrière. Ni fortune. Ni biens matériels. Ni biens spirituels. Ni présent. Ni avenir"

31 "sans patrie, sans territoire, mais aussi sans domicilie, sans travail, sans papiers, sans droit à un espace de parole"

32 "Rosélie se garda de tout commentaire, elle qui se refusait à juger, à condamner, à questionner"

33 "Comme toujours, Stephen parlait pour deux"

34 "Rosélie manquait d'énergie pour se défendre"

35 "Je niais la vérité pour n'avoir pas à décider"

36 "insécurité"
} 
própria vida. Tem no marido muito mais que o arrimo da família; é dele que lhe vem a parca dignidade possível, os espasmos de vida. Segundo Fabienne Viala, Rosélie é aquela "perdida num corpo que até então habitou apenas por refração, como uma excrescência dependendo daquele que lhe dava status e identidade" 37 (2010, p. 134). E neste momento se enfatizam as narrações que tecem a intriga: sob um ângulo, um narrador que não hesita em pintar as fragilidades de Rosélie e, sob outro ângulo, uma narradora que exerce o protagonismo de seu olhar, a despeito de todas as suas vulnerabilidades. O jogo se constrói a partir da premissa de ver e ser vista, do eu e do outro, o que evoca o mundo da pintura, com o veremos mais adiante.

Em Histoire de la femme cannibale, o casal não teve filhos nem se casou oficialmente. A avó do inglês vociferava que "nunca e em tempo algum ela poderia segurar um neto mestiço nos braços"38 (CONDÉ, 2012, p.59). Afinal, perguntava-se retoricamente a matriarca: “os mestiços não são a abominação da abominação?"39 (CONDÉ, 2012, p.59) Incrédula, Rosélie fazia alusão à força da vigência do Código negro ${ }^{40}$, quatro séculos após o processo de escravização: "proibamos nossos sujeitos brancos de um ou outro sexo de contrair casamento com os negros, sob pena de punição e de multa arbitrária"41 (CONDÉ, 2012, p.59). Em outra cena, Rosélie se vê acusada pela colega e militante Dominique de trair a raça (CONDÉ, 2012, p.89) ao ter se unido a um homem branco. Outra personagem, Olu Ogundipe, profere a máxima: "se nós não amamos nossa cor, como podemos censurar os brancos por não amá-

\footnotetext{
37 “perdue dans un corps de femme qu'elle n'a jusqu'alors habité que par réfraction, comme une excroissance dépendant de celui qui lui donnait statut et identité"

38 "Jamais au grand jamais elle ne pourrait serrer un petit-fils métis dans ses bras"

39 "Les métis ne sont-ils pas l'abomination des abominations ?"

${ }^{40}$ Promulgado em 1685, em Marselha, pelo rei francês Louis XIV, o Código negro consistiu na reunião de 60 artigos responsáveis pela organização jurídica da escravização de negros nos territórios ocupados além-mar pelo Estado francês. Redigido pelo ministro das colônias Colbert (que faleceu dois anos antes da promulgação do texto), o conjunto de leis coloca em relevo a onipresença da igreja católica como fé a ser imposta nos novos territórios à revelia de demais cultos existentes e sob pena de sanções rigorosas. Para além do incontornável tema religioso, o documento versa sobre o regime de trabalho, a alimentação, a vestimenta, o casamento, os negros livres, as festividades, as punições e os castigos corporais a serem infligidos em cativos desobedientes, além de mencionar algumas obrigações dos proprietários. Houve uma segunda versão do texto, de 1724, com a supressão de alguns artigos; a primeira versão, contudo, permanece a mais conhecida.

A título de ilustração, podemos mencionar o fato de a estátua de Colbert, localizada diante da Assembleia Nacional Francesa em Paris, ter sido atacada no início de junho de 2020, na esteira de movimentos decoloniais que colocam em xeque a permanência de monumentos celebrando a empreitada imperialista em via pública. Na ocasião, uma tinta vermelha foi lançada na estátua e as palavras de ordem "Negrofobia do estado" acrescentadas ao pedestal. Em resposta à crescente ocorrência de degradações em estátuas, o presidente Emmanuel Macron preconizou, em pronunciamento oficial em 14 de junho de 2020, que "a República não apagará nenhum vestígio ou nome de sua história. A República não retirará uma estátua. Devemos, sobretudo, olhar de maneira lúcida e juntos para nossas memórias, nosso relacionamento com a África em particular". (BEAUMONT, 2020) Sobre este tema, ver 20 MINUTES SOCIÉTÉ, 2020.

41 "Défendons à nos sujets blancs de l'un et l'autre sexe de contracter mariage avec les Noirs, à peine de punition et d'amende arbitraire"
} 
la?"42 (CONDÉ, 2012, p. 265)

Nesta perspectiva, "os estereótipos em relação às mulheres antilhanas têm vida dura. Elas deveriam odiar e desprezar os Peles negras"43 (CONDÉ, 2012, p.264). O casal experimenta, nessa toada, uma superposição de condenações: a família de Stephen o critica por ter desposado uma negra enquanto Rosélie se vê atacada porque está ao lado de um homem branco. Viúva, Rosélie inicia um relacionamento com Faustin, que lhe sentencia: "é preciso reintegrar; você viveu tempo demais com os brancos" ${ }^{\prime 4}$ (CONDÉ, 2012, p. 124), ao longo da cena em que decide convidá-la para uma apresentação de música do Zaire no bairro de moradores do Malawi. No campo amoroso, cria-se um descompasso constante entre Rosélie e seus amantes: ou ela é negra em um mundo preconceituoso que a exclui ou ela traiu os negros e se embranqueceu no contato com o marido, sua família e seus costumes. Logo, Rosélie se encontra impreterivelmente deslocada, não conseguindo agradar os demais nem ser acolhida por nenhum dos lados. Eis o cenário de onde emergem sua solidão implacável e sua fragilidade atroz.

Quando do ataque à queima-roupa sofrido por Stephen, que lhe tiraria posteriormente a vida, Rosélie se torna vítima de um interrogatório pelo corpo médico do hospital, interrogatório que se realizava não apenas por intermédio da curiosidade inquisitiva como também e, principalmente, se depreendia pelos traços de espanto na fisionomia dos profissionais de saúde:

Você quer nos fazer acreditar que é a pessoa mais próxima dele? Qual relação você tinha com ele? Você, sua mulher? Que gosto perverso e degenerado tinha este belo inglês? Onde está a mãe dele? Seu pai? Sua irmã? Não há mais ninguém além de você? De qual país da África você é? Guadalupe, onde fica? O que você veio buscar na Cidade do Cabo? O que você faz aqui? ${ }^{45}$ (CONDÉ, 2012, p.102).

Às vésperas de perder o marido, ela esteve diante de rostos inquisidores que lançaram dúvidas e censuras sobre sua união amorosa. Ao vivenciar uma situação de imensa vulnerabilidade, não se vê acolhida e, deste modo, rasuram-se a empatia e a cordialidade do convívio social. Este episódio corrobora a máxima de que aos negros são sempre destinadas

\footnotetext{
42 "Si nous n'aimons pas notre couleur, comment pouvons-nous reprocher aux Blancs de ne pas l'aimer ?"

43 "Les stéréotypes concernant les femmes antillaises ont la vie dure. Elles sont censées haïr et mépriser les Peaux Noirs"

44 "Il faut réintégrer; tu as trop vécu avec les Blancs"

45 "Vous voulez nous faire croire que vous êtes la personne la plus proche ? Quel rapport avez-vous avec lui ? Vous, sa femme ? Quel goût pervers et dégénéré avait ce bel Anglais ? Où est sa mère ? Son père ? Sa sœur? Il n'y a personne d'autre que vous? De quel pays d'Afrique êtes-vous? La Guadeloupe, où est-ce? Qu'est-ce que vous y faites?
} 
as inquisições, as desconfianças; afinal, há de reiterar a polêmica máxima de que "um negro é sempre culpado"46 (CONDÉ, 2012, p. 257). Na cena do hospital, há apenas o desfile - de natureza quase militar - de perguntas e ilações. Mais uma vez, não se ouve a voz da personagem. Suas respostas ficam subentendidas no rol de perguntas. Tal procedimento manifesta a hierarquia de vozes que assola a Cidade do Cabo em pleno período pós-apartheid, no qual as fissuras sociais e as segregações raciais não saíram de cena. A este propósito, a escritora Maryse Condé confessa em entrevista: "quando eu era jovem, pensava sinceramente que construiríamos um mundo melhor onde os homens seriam irmãos, onde o racismo e a dominação mútua teriam desaparecido. Eu estava errada"47 (LARCHER, 2019). E assim, a autora transforma a ingenuidade de outrora num ceticismo permanente deflagrado no conjunto de sua obra.

O romance Histoire de la femme cannibale (2003) toma seu nome emprestado, como revela Maryse Condé no paratexto da obra, do quadro Cannibalisme (1995), óleo sobre tela do pintor guadalupense Michel Rovélas. O quadro nos é apresentado por Anne-Catherine Berry em sua tese de doutorado, intitulada "O corpo arquipélago nas artes plásticas nas Antilhas francesas", defendida em 2017, na Université des Antilles:

Em outras pinturas, esses mesmos atributos femininos parecem túrgidos, da boca aos lábios pintados de vermelho puro, passando pelos seios inchados, até a vulva oferecida ao olhar, sem nenhuma vergonha. Podemos ver isso particularmente em Disloquements II e Cannibalisme. De maneira recorrente, esse corpo feminino parece destituído de alguns de seus membros, de suas extremidades mais particularmente; nem os braços nem as pernas são mostrados na íntegra, ou aparecem apenas em parte, com exceção de alguns casos. Além disso, as poses a que essas figuras são submetidas se mostram, em muitos casos, muito expressivas e sofrem exageros, distorções, deformações. Emana de algumas delas mais particularmente certa violência, como se estivessem divididas entre conflitos internos e tensões externas. $\mathrm{O}$ corpo é esquartejado, distorcido, abusado, contorcido, truncado e desmembrado, sem dúvida desfigurado ${ }^{48}$ (BERRY, 2017, p.144).

\footnotetext{
46 "Un Noir est toujours coupable"

47 “Quand j'étais jeune, je pensais sincèrement que nous allions bâtir un monde meilleur où les hommes seraient des frères, où le racisme et la domination des uns par les autres auraient disparu. Je me suis trompée"

48 "Dans d'autres toiles, ces mêmes attributs féminins apparaissent turgescents, de la bouche aux lèvres fardées de rouge pur, en passant par les seins engorgés, jusqu'à la vulve offerte au regard, sans pudeur aucune. Nous pouvons l'observer particulièrement dans Disloquements II et Cannibalisme. De manière récurrente, ce corps féminin semble destitué de certains de ses membres, de ses extrémités plus particulièrement ; ni bras ni jambes ne sont indiqués dans leur intégralité, ou n'apparaissent qu'en partie, à l'exception de quelques cas. De plus, les postures auxquelles sont soumises ces figures s'avèrent, en de nombreux cas, très expressives et subissent des exagérations, des distorsions, des déformations. Il émane de certaines d'entre elles plus particulièrement une violence certaine, elles sont comme tiraillées entre des conflits intérieurs et des tensions extérieures. Le corps est écartelé, distordu, malmené, contorsionné, tronqué et démembré il est incontestablement défiguré”
} 
E a presença de Rovélas se torna fundamental pelo fato de que, só agora mencionamos, Rosélie "não sabia nada além de pintar"49 (CONDÉ, 2012, p.18). Para além da explicação de que o nome Rosélie se forja na aglutinação dos nomes materno "Rose" e paterno "Élie" (CONDÉ, 2012, p.13), nos ocorre que as aliterações e as assonâncias que aproximam os nomes dos pintores, uma dança de /r/o/é/l/ distribuídas uniformemente em três sílabas celebra o encontro pictórico entre 'criador' e 'criatura'. Rosélie só sabe pintar (CONDÉ, 2012, p. 62), "não podia se impedir de pintar. Pintar como um condenado acorrentado"50 (CONDÉ, 2012, p.63) e se apressa em "se fechar em seu ateliê"51 (CONDÉ, 2012, p.62), lugar refúgio impenetrável onde seu véu de invisibilidade cai por terra para si mesma. A ação de se fechar no ateliê surge como uma ladainha, um refrão para o cântico triste entoado no romance. E a personagem, para além de invisibilizada e ignorada, assume a faceta do isolamento, do confinamento em si, nas tintas e telas. Se o mundo não lhe acolhe, ela, por sua vez, também recusa o mundo. Sua realização se restringe a este espaço solitário no qual consegue produzir, 'desparasitar' sua existência. Ali não fica atrás dos demais, não se relega à coxia e assume o protagonismo possível. Quando pinta, não sente fome (CONDÉ, 2012, p.63), saciada, como se pode deduzir, de arte e pela arte em sua capacidade de desmobilizar os revezes e desarmar o parasitismo do dia a dia. Uma importante exceção à redoma, criada pelo ateliê, se impõe na intriga do romance: nele, Rosélie inicia um caso amoroso, extraconjugal, com o artista Ariel Echevarriá, único homem autorizado a adentrar no refúgio. A fricção com Rovélas se materializa nas telas de Rosélie, onde há

muito vermelho. Não o vermelho vivo como o sangue que banha os nascimentos, mas o escuro, coagulado como aquele que fecunda os mortos. Esta cor sempre a obcecou. (...) Ela pintava também o marrom escuro, o cinza, o preto, o branco. Stephen não intervinha, mas se espantava. Por que sempre temas tão horríveis? Corpos desmembrados, torsos, olhos exaustos, baços, fígados estourados ${ }^{52}$ (CONDÉ, 2012, p. 62-63).

Não obstante, o falecimento de Stephen a lança num movimento de suspensão criativa, um luto que só será sanado na página final do romance. Enquanto não pinta, trabalha como curandeira e massagista, povoando seu parco mundo com poucas dezenas de clientes. O isolamento se esvai. Condé analisa este novo momento da personagem:

\footnotetext{
49 "elle ne savait rien d'autre que peindre"

50 “elle ne pouvait s'empêcher de peindre. Peindre comme un forçat à la chaîne"

51 "s'enfermer dans son atelier"

52 "Beaucoup de rouge. Non pas um rouge vif comme le sang qui baigne les naissances, mais sombre, caillé comme celui qui féconde les morts. Cette couleur l'avait toujours obsédée. (...) Elle peignait aussi le marron sombre, le gris, le noir, le blanc. Stephen n'intervenait pas, mais s'étonnait. Pourquoi toujours des sujets si horribles ? Corps démembrés, moignons, yeux crevés, rates, foies éclatés"
} 
Todas as heroínas dos meus romances, por exemplo, se perguntam: como realizar-se não apenas como ser humano, mas como mulher, fora das passagens obrigatórias, amor e maternidade? Rosélie em Histoire de la femme cannibale é pintora, mas se pergunta se ela não pinta com os olhos de seu companheiro, Stephen. É só quando Stephen morre que ela pode se libertar. Eu sempre falo sobre intolerância, eu me esforço sempre em destruir mitos. Eu enfrento as ideias preconcebidas.$^{53}$ (ALI-BENALI, 2009, p.16-17).

Rosélie aventa a possibilidade de trabalhar com a pintura para honrar seus compromissos financeiros, uma vez que vivia em concubinato e não teve direito à herança do marido. Todavia, "a pintura não é como a música, piano, guitarra ou clarinete. Um pianista, um guitarrista, um clarinetista podem sempre dar aulas às crianças mediante um pagamento por hora. A pintura é como a literatura. Sem lucro material nem utilidade imediatos" 54 (CONDÉ, 2012, p.18-19). A ideia se ameniza diante da constatação de que "às vezes, a escrita pode servir para alguma coisa"55 (CONDÉ, 2012, p.39). O jogo romanesco proposto por Maryse Condé se alimenta ainda de provocações, como as que se vê nas sentenças a seguir: "ela não lia. (...) As histórias que se escreve não chegam nunca ao calcanhar da realidade"56 (CONDÉ, 2012, p.27) e "as únicas criações válidas são as do imaginário"57 (CONDÉ, 2012, p.63). Através de Rosélie, que não consegue expor seus trabalhos em galerias relevantes e não se faz reconhecer como artista, Condé incita o debate acerca da importância da arte, definida assim no livro: "A arte, a cultura são compensações necessárias ligadas à infelicidade de nossas vidas ${ }^{58 "}$ (CONDÉ, 2012, p. 182) e "a arte é a única linguagem que se compartilha na superfície da Terra sem distinção de nacionalidade nem de raça, estas duas pragas que impossibilitam a comunicação entre os homens"59 (CONDÉ, 2012, p. 196).

Em Histoire de la femme cannibale há a superposição de inutilidades práticas que aproximariam pintura e literatura, instâncias que se oferecem, no senso comum, tão apenas ao deleite. E a partir desta interface, se acentua a invisibilidade social de Rosélie: pintora e

\footnotetext{
53 “Toutes les héroïnes de mes romans par exemple s'interrogent : comment se réaliser non pas seulement en tant qu'être humain, mais en tant que femme, en dehors des passages obligés, l'amour et la maternité ? Rosélie dans Histoire de la femme cannibale est peintre, mais se demande si elle ne peint pas avec les yeux de son compagnon, Stephen. C'est seulement quand Stephen est mort qu'elle arrive à se libérer. Je parle toujours d'intolérance, je m'efforce toujours de détruire les mythes. Je m'attaque aux idées reçues"

54 “La peinture n'est pas comme la musique, piano, violon ou clarinette. Un pianiste, un violoniste, un clarinettiste peuvent toujours donner des leçons aux enfants moyennant un paiement de l'heure. La peinture est comme la littérature. Sans profit matériel ni utilité immédiats"

55 "parfois, l'écriture peut servir à quelque chose"

56 “elle ne lisait pas (...) les histoires qu'on écrit n'arrivaient jamais à la cheville de la réalité”

57 "Les seules créations valables sont celles de l'imaginaire"

58 "L'art, la culture sont des compensations nécessaires liées au malheur de nos vies". A frase é retomada ipsis litteris mais adiante na página 266 do romance, seguida da informação "(bis)".

59 "l'art est le seul langage qui se partage à la surface de la Terre sans distinction de nationalité ni de race, ces deux fléaux qui interdisent la communication entre les hommes"'
} 
narradora de sua trajetória e, portanto, duplamente descartável na tessitura social. Vive, assim, a parasitar o marido professor de literatura: ele transforma sua arte em lições da formação universitária de terceiros e em ofício remunerado enquanto ela produz apenas para si. Segundo a pesquisadora Thérèse Migraine-Georges, na contramão do senso comum que apequena o valor da literatura e da pintura, "através da arte, Rosélie se redefine e renasce como mulher não apenas artista, mas também canibal, não sendo mais devorada pelo mundo, mas devorando, por sua vez, para melhor recriá-lo à medida"60 $(2010$, p. 507). Eis o ponto de virada da narrativa, o lado de pintora que canibaliza. Ora, só canibaliza quem está vivo e robusto, a despeito das dores que carrega junto a si. Ao canibalizar, Rosélie pulveriza o parasitismo de outrora e se lança num ímpeto de criação, a criação que já existiu em sua vida, mas que se refreou ao longo do casamento e, principalmente, na viuvez.

\section{EMBATES E DIMENSÕES DO CANIBALISMO}

Não podemos perder de vista, no âmbito da segregação racial que já contemplamos, que "Rosélie se sente humilhada e de alguma forma 'consumida' por olhares que não são capazes de vê-la como uma pessoa inteira, mas reduzi-la a uma raça, um sexo, ou percebê-la como uma prostituta de luxo em seu relacionamento com Stephen"61 (MIGRAINEGEORGES, 2010, p.513). E aqui se apresenta mais uma faceta da personagem: o apreço pelo canibalismo através do adágio "sempre os canibais me interpelaram"62 (CONDÉ, 2012, p.245). Para compreendermos como o canibalismo opera no romance, propomos um segundo espelhamento, não mais com a Cidade do Cabo e seu caos, mas com a personagem Fiéla. A aparição de Fiéla ocorre no capítulo cinco através de uma notícia no periódico Tribune du Cap. Ela foi presa, acusada de ter assassinado o marido, esquartejado seu corpo e guardado os pedaços em sacos de plástico no congelador (CONDÉ, 2012, p.95). Ao passo que a empregada Dido lamenta a selvageria da cidade, horrorizada diante do crime brutal, Rosélie "fascinada, observava a foto desta Fiéla"63 (CONDÉ, 2012, p. 96) e profere a sentença "ela tem minha idade [50 e poucos anos]. Ela não é bonita. Poderia ser eu" ${ }^{\circ 4}$ (CONDÉ, 2012, p. 96).

\footnotetext{
60 “A travers l'art, Rosélie se redéfinit et renaît en femme non seulement artiste mais aussi cannibale, ne se laissant plus dévorer par le monde mais le dévorant à son tour pour mieux le recréer à sa mesure"

61 "Rosélie se sent humiliée et 'consommée' en quelque sorte par des regards qui ne sont pas capables de la voir comme une personne entière mais la réduisent à une race, un sexe, ou la perçoivent comme une prostituée de luxe dans sa relation avec Stephen"

62 "Toujours les cannibales m'ont interpellée"

63 "Rosélie, fascinée, considérait la photo de cette Fiéla"

64 "Elle a mon âge. Elle n'est pas belle. Elle pourrait être moi"
} 
A simbiose entre as duas se acentua ao longo do romance. Durante um pesadelo, Rosélie associa Fiéla a uma "irmã gêmea, separada dela no nascimento e reencontrada cinquenta anos mais tarde" ${ }^{65}$ (CONDÉ, 2012, p. 263). Perante a pergunta "Por que você fez isso", Fiéla responde "Fiz por você! Por você!"66 (CONDÉ, 2012, p. 263) Mais adiante, quando Fiéla recebe a sentença de quinze anos de reclusão após um julgamento de dez dias no qual se manteve em silêncio e abdicou de testemunho oral, Rosélie descreve a foto que estampava o jornal: "de pé entre seus guardas, uma mulher vara pau, como eu, o rosto enigmático, como eu, se preparando para acrescentar seu nome na já longa lista de loucas e feiticeiras" ${ }^{67}$ (CONDÉ, 2012, p. 301). Se num primeiro momento, a viuvez, a idade e a pouca beleza as aproximaram, rapidamente o silêncio, o desprezo alheio, a fraternidade se impuseram neste espelhamento. Por fim, a relação entre traição e morte acentua esta ligação feminina. Enquanto Fiéla tira a vida do marido por causa, supõe-se, da traição e dos filhos fora do casamento, Stephen foi assassinado pelo amante, com quem manteve um caso extraconjugal por mais de dois anos. Como afirma o narrador, unindo os fios das histórias, "falar de Fiéla. De Stephen também. Atualmente, as duas histórias se misturavam em sua cabeça"68 (CONDÉ, 2012, p.302).

A partir de então, novos dados se somam ao jogo de espelhamento entre as personagens: pesa sobre uma a acusação de que comeria a carne do marido, enquanto a pintora em alguma medida parasitava o marido, alimentando-se de sua vivacidade, de seus contatos sociais, de sua desenvoltura e de sua inteligência. Se Rosélie era um "nada", como já mencionamos, Stephen representava o exato oposto: sucesso, charme e vigor. Há entre as duas mulheres uma aproximação de relação de forças que se imprimem no corpo masculino: a assassina e a sugadora, duas faces da mesma moeda. Uma e outra, em alguma medida, precisam dos maridos, seja para comê-los, seja para vampirizá-los. Rosélie se define pelo seguinte mote: "Amo o horror. Acredito que em uma vida anterior fiz parte de um grupo de vampiros. Meus caninos longos e pontiagudos perfuraram o seio da minha mãe"69 (CONDÉ, 2012, p. 63).

Neste sentido, "a mulher canibal pode ser vista de maneira mais radical, não apenas como uma mulher castradora capaz de devorar e consumir o corpo masculino, mas também

\footnotetext{
65 "S $œ u$ jumelle, séparée d'elle à la naissance et retrouvée cinquante ans plus tard"

66 "Pourquoi est-ce que tu as fait cela?" "J'ai fait cela pour toi ! Pour toi !"

67 "Debout entre ses gardes, une grande gaule de femme, comme moi, la figure énigmatique, comme moi, se préparant à ajouter son nom à la liste déjà longue des folles et des sorcières"

68 "Parler de Fiéla. De Stephen aussi. À présent, les deux histoires se mêlaient dans sa tête"

69 “J'aime l'horreur. Je crois que dans une vie antérieure j'ai fait partie d'une portée de vampires. Mes canines longues et pointues ont perforé le sein de ma mère"
} 
como uma mulher fálica com dentes penetrantes"70 (MIGRAINE-GEORGES, 2010, p.513). Assim, Fiéla e Rósélie se aproximam igualmente pelo intermédio da morbidez, da raiva, da cor vermelha, da destruição do corpo alheio, torsos, braços e pernas que aludem à pintura canibalizada de Rosélie/Rovélas. Na infância, durante a aula de desenho da escola, Rosélie ilustra "uma mulher, pernas abertas de onde escorria uma fonte de sangue"71 (CONDÉ, 2012, p. 177), um desenho aludindo ao estupro. A professora se apressa a perguntar quem a viola, ao que ela responde "tranquilamente": "meu pai, minha mãe, todo o mundo"72 (CONDÉ, 2012, p. 177). Graças ao impulso de Fiéla, Rosélie retoma a pintura onde produz quadros que trazem à tona a violência que vê à volta e a qual se sente conectada.

Sob outro ponto de vista, a respeito da relação Stephen-Rosélie, é possível vislumbrar que "ela foi usada, canibalizada de alguma forma por seu companheiro de vinte anos. Então está no mistério da mulher canibal, no enigma e na opacidade que essa figura representa, ao mesmo tempo real e imaginário, que Rosélie encontrará sua inspiração pessoal"73 (MIGRAINE-GEORGES, 2010, p. 511). A menção ao canibalismo se reinveste em conversa entre Amy e Rosélie, na qual a primeira sugere que Rosélie era devorada pelo marido: "Devorada por devorada, prefiro ser por meus filhos. Ela queria dizer que ela era devorada por Stephen?"74 (CONDÉ, 2012, p.210) E isto se confirma pelo fato de Stephen ter mascarado sua homossexualidade (ou bissexualidade) graças ao casamento pacato e acima de qualquer suspeita com Rosélie. De fato, ela só descobre a nova orientação sexual do marido a partir do inquérito que esclareceu sua morte, junto do qual se desvendam urdiduras de traições, infidelidades, desrespeitos e deslealdades. A vida fora do ateliê de pintura se desmorona como um castelo de areias.

A primeira menção à mulher canibal no romance correspondente à reação dos alunos de Stephen quando Rosélie compareceu a uma apresentação teatral organizada pelo marido:

Ela teve a impressão de prejudicar a imagem deste professor tão amado, que falava inglês com um sotaque formidável e exibia em todo o corpo um refinamento do Velho Mundo. Qual vínculo pouco saudável o unia àquela descendente dos canibais? Fiéla, Fiéla, você está vendo? Nós nos

\footnotetext{
70 "la femme cannibale peut être vue de manière plus radicale non seulement comme une femme castratrice capable de dévorer et de consommer le corps masculin mais aussi comme une femme phallique aux dents pénétrantes"

71 "une femme, jambes écartées d'où coulait une fontaine de sang"

72 "tranquillement: 'Mon papa, ma maman, tout le monde'."

73 "Rosélie, qu'elle a été utilisée, cannibalisée en quelque sorte, par son compagnon de vingt ans. C'est donc dans le mystère de la femme cannibale, dans l'énigme et l'opacité que représente cette figure tout à la fois réelle et imaginaire, que Rosélie va trouver son inspiration personnelle"

74 "Dévorée pour dévorée, je préfère l'être par mes enfants"
} 
parecemos $^{75}$ (CONDÉ, 2012, p. 117).

E assim, a narrativa oferece novas camadas de leitura para o termo, evocando a história das Américas e dos indígenas. O âmbito privado ascende ao coletivo, o drama pessoal ganha contornos de fato histórico. Nas palavras de Mondher Kilani

a palavra 'canibal' nasce com o descobridor da América, Cristóvão Colombo. O termo Caniba, que é uma alteração do termo Carib, pelo qual referem-se a si mesmos como os índios Caraíbas, imediatamente se mistura ao imaginário do viajante ilustre que desembarca nas margens do que mais tarde se chamará Cuba, onde ele acha que vai encontrar ciclopes, 'homens e mulheres com apenas um olho', e cinocéfalos, 'homens com focinhos de cachorro que comiam seres humanos'. A palavra canibale surge em sua boca de 26 de novembro de 1492 para se referir tanto ao canis latino tanto os índios Caribs, monstros que devoram carne humana ${ }^{76}$ (2006, p. 34).

No romance, Stephen faz menção aos índios tupinambás ao se reconhecer, ele também, como canibal: "Vivia através de outros homens. Como um índio tupinambá, devorava fígado, baço, coração"77 (CONDÉ, 2012, p. 178). Rosélie reporta a reprodução de uma obra de André Trevet de 1522: "Festa nos índios Tupinambás canibais"78 (CONDÉ, 2012, p. 245). O frade franciscano francês Thévet foi o primeiro etnógrafo dos Tupinambás, tendo escrito o livro Singularidades da França Antártica, em 1557.

Levando-se em conta que "o canibalismo não pode ser isolado, é uma questão de todas as representações que uma sociedade faz de si mesmo e de outros. É um fenômeno social

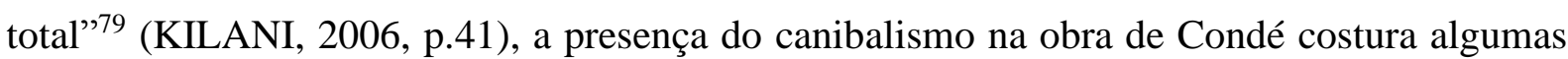
dimensões, a saber: menção à origem das Américas e ao desmantelamento original provocado pela empreitada colonial; menção ao ato de "incorporar uma parte do corpo do outro para recuperar força e saúde, à imagem do ato canibal selvagem que deveria se apropriar da força e

\footnotetext{
75 “Elle avait eu l'impression de nuire à l'image de ce professeur bien-aimé, qui parlait l'anglais avec un accent inimitable et affichait sur toute sa personne le raffinement du Vieux Monde. Quel lien malsain l'unissait à cette descendante des cannibales? Fiéla, Fiéla, tu vois, nous nous ressemblons"

76 "Le mot 'cannibale' naît avec le découvreur de l'Amérique, Christophe Colomb en personne. Le vocable Caniba qui est une altération du terme Carib, par lequel se désignent les Indiens des Antilles, se mêle tout de suite à l'imaginaire de l'illustre voyageur qui débarque sur les côtes de ce qui va prendre plus tard le nom de Cuba où il pense rencontrer, comme il se doit, des cyclopes, des 'hommes avec un seul œil', et des cynocéphales, des 'hommes avec des museaux de chien qui mangeaient les êtres humains' Le mot canibale surgit dans la bouche de l'amiral le 26 novembre 1492 pour désigner aussi bien le chien latin canis, les Indiens Caribs, les monstres dévoreurs de chair humaine"

77 "Je vivais au travers d'autres hommes. Comme un Indien Tupinamba, je dévorais leur foie, leur rate, leur coeur"

78 "Un festin chez les Indiens Tupinamba cannibales"

79 "le cannibalisme ne peut être isolé, il relève de l'ensemble des représentations qu'une société se fait d'ellemême et d'autrui. Il est un phénomène social total"
} 
da coragem da pessoa sacrificada" 80 (KILANI, 2006, p. 44) e menção metafórica, na esteira da segunda acepção, de "mosaico identitário"81 (CHAMOISEAU, 2011, p. 246), soma de vozes dispostas em palimpsesto, corpo formado por outros corpos, árvore com frutos diversos. O mecanismo evoca o manifesto antropofágico de 1928, movimento capitaneado pelo escritor e ensaísta brasileiro Oswald de Andrade no qual era imperativo repensar a dependência cultural brasileira e dar a ver uma arte genuinamente 'tupiniquim'. Buscava-se uma alforria intelectual advinda do colonialismo e de seu legado assimilacionista. Marco do modernismo brasileiro, o manifesto foi publicado na Revista da Antropofagia, fundada por Andrade e pelos escritores Raul Bopp e Antônio de Alcântara Machado. Eis alguns trechos do célebre manifesto:

Só a Antropofagia nos une. Socialmente. Economicamente. Filosoficamente. Única lei do mundo. Expressão mascarada de todos os individualismos, de todos os coletivismos. De todas as religiões. De todos os tratados de paz.

Tupi, or not tupi, that is the question.

Contra todas as catequeses. E contra a mãe dos Gracos.

Só me interessa o que não é meu. Lei do homem. Lei do antropófago.

(...) Queremos a Revolução Caraíba. Maior que a Revolução Francesa. A unificação de todas as revoltas eficazes na direção do homem. Sem nós a Europa não teria sequer a sua pobre declaração dos direitos do homem.

Não podemos perder de vista de que a antropofagia consiste em um tipo de canibalismo. Nas palavras de Andrade

\begin{abstract}
A reabilitação do primitivo é uma tarefa que compete aos americanos. Todo mundo sabe o conceito deprimente de que se utilizaram os europeus para fins colonizadores. [...] Devido ao meu estado de saúde, não posso tornar, mais longa esta comunicação que julgo essencial a uma revisão de conceitos sobre o homem da América. Faço, pois um apelo a todos os estudiosos desse grande assunto para que tomem em consideração a grandeza do primitivo, o seu sólido conceito de vida como devoração e levem avante toda uma filosofia que está para ser feita (1992, p. 231-232).
\end{abstract}

Neste sentido, "a antropofagia preconiza uma espécie de transubstanciação na qual aquele que é o devorador se altera no devorado. A 'morte' e 'devoração' do outro recria o próprio; dentro desta perspectiva, o discurso ressentido das relações coloniais torna-se discurso produtivo de identidades" (ALMEIDA, 2001, p. 95). O projeto, como evidencia Andrade na velhice, deveria ter as rédeas tomadas pelas próximas gerações num esforço cultural de auto-conhecimento e de deglutição crítica dos mais diversos componentes e

80 “s'incorporer une partie du corps de l'autre pour retrouver force et santé, à l'image de l'acte cannibale sauvage censé s'approprier la force et le courage de la personne sacrifiée"

81 "mosaïque identitaire" 
influências para a criação de uma arte nacional autêntica. A antropofagia e o canibalismo apontam para a destruição simbólica que almeja a soma, a alteridade, a comunhão. Ambos flertam com a paródia, a revolta, a subversão, a dessacralização de paradigmas e a desnaturalização das hierarquias que inspiram o pensamento decolonial.

Retomando o universo literário de Maryse Condé,

parece que o canibalismo feminino neste romance adquire uma dimensão alegórica mais densa: não se trata apenas de uma metáfora para dizer a alteridade feminina e gritar a sede de independência (....) mas de uma imagem ancorada no imaginário coletivo ${ }^{82}$ (VIALA, 2010, p. 136-137).

De fato,

não é por acaso que Condé empresta a imagem do canibalismo que reativa um estereótipo da crônica americana - e de alguma violência tribal. Isso a permite criticar sua sustentabilidade simbólica e, portanto, chamar a libertarse dos pressupostos atávicos que condicionam o imaginário cultural. É assim que o leitor, surpreso em sua passividade é convocado para imaginar a terra incógnita do futuro, livre do legado da violência. (... ) a história de mulher canibal como uma metáfora para trabalho do artista que se alimenta do drama de seus companheiros, para consolidar seu próprio mundo interior, reconhecendo-se a si mesma na solidão do outro $^{83}$ (TREMBLAY, 2004, p.56).

Após o suicídio de Fiéla na prisão e o desfecho do assassinato do marido, que lançou Rosélie para as manchetes do jornal Tribune du Cap em um escândalo midiático de grandes proporções, ela vislumbra o suicídio antes de ponderar: "Fiéla, pensando bem, você não me deu o exemplo. Você escolheu morrer. Não é que se deve morrer. Deve-se viver. Agarrar-se na vida. Obstinadamente" ${ }^{\nexists 4}$ (CONDÉ, 2012, p. 349-350). Acolhendo a pulsão de vida e de criação, a personagem retoma a pintura de maneira energética e visceral, como se lê na parte final do livro:

\footnotetext{
82 "Il semble bien que le cannibalisme féminin dans ce roman acquiert une dimension allégorique plus dense : il ne s'agit plus seulement d'une métaphore pour dire l'altérité féminine et crier soif d'indépendance (...) mais d'une image ancrée dans l'imaginaire collectif'

83 “Il n'est pas fortuit que Condé emprunte l'imagerie du cannibalisme qui réactive un stéréotype de la chronique américaine - et d'une certaine violence tribale. Cela lui permet d'en critiquer la pérennité symbolique et, par conséquent, d'appeler à se libérer des présupposés ataviques qui conditionnent l'imaginaire culturel. C'est ainsi que le lecteur, surpris dans sa passivité, est sommé d'imaginer la terra incognita du futur, libéré du legs de la violence. (...) l'histoire de la femme cannibale comme une métaphore du travail de l'artiste qui s'alimente à même le drame de ses semblables, pour consolider son propre monde intérieur en se reconnaissant soi-même dans la solitude de l'autre"

84 “Fiéla, tout bien réfléchi, tu ne m'as pas donné l'exemple. Tu as choisi de mourir. Or, ce n'est pas mourir qu'il faut mourir. C'est vivre qu'il faut vivre. S'accrocher à la vie. Obstinément"
} 
Rosélie selecionou cuidadosamente uma tela: cento e dez centímetros por cento e trinta. Ela a prendeu na parede. Agarrando um lápis, sua mão rápida, precisa, desenhou um par de olhos no meio. Os olhos que tanto a tinham impressionado $^{85}$ (CONDÉ, 2012, p. 351).

Ao se perceber frente a frente aos olhos na tela, a protagonista questiona: "Fiéla, é você? Sou eu? Nossas duas figuras se confundem" 86 (CONDÉ, 2012, p. 352) antes de ceder à palavra final ao narrador: "Desta vez, ela possuía um título. Ela o tinha encontrado antes mesmo de começar sua obra. Ele tinha surgido do mais profundo dela mesma no fim de uma maré incontrolável: Mulher canibal" ${ }^{\prime 87}$ (CONDÉ, 2012, p.352- grifo do autor). Ora,

esse renascimento de Rosélie como mulher canibal é motivado por uma perda total e dolorosa de significado, uma tábula rasa existencial da qual extrai um novo poder criativo simbolizado especialmente pelo fato de ela poder nomear sua matriz (enquanto normalmente ela não consegue encontrar títulos para suas pinturas) ${ }^{88}$ (MIGRAINE-GEORGES, 2010, p.514 - grifo do autor).

Os quadros operam um chamamento da pintora enlutada para a seara artística: "se você não pinta mais, você não vive mais. Quando você voltará para nós?"89 (CONDÉ, 2012, p. 307) A metáfora deste chamamento pode ser lida como vozes de um passado e de um presente que ecoam. Como salienta Condé, "há uma forte tradição do que é chamado de canibalismo literário no Caribe"90 (WOLFF, 1999). Em sua fala, Condé recupera a sentença de Suzanne Césaire" ${ }^{11}$, na véspera da Segunda Guerra Mundial, quando "na revista Tropiques, proferiu seu famoso comando: 'A poesia martinicana deve ser canibalista ou não será'",92

85 "Rosélie sélectionna soigneusement une toile: cent dix centimètres sur cent trente. Elle la fixa au mur. S'emparant d'un crayon, sa main rapide, précise, dessine une paire d'yeux en son mitan. Les yeux qui l'avaient tellement impressionnée"

86 "Fiéla, est-ce toi? Est-ce moi? Nos deux figures se confondent"

87 “Cette fois, elle était en possession de son titre. Elle l'avait trouvé avant même que de commencer son ouvrage. Il avait surgi du plus profond d'elle-même au bout d'une marée incontrôlable : Femme cannibale"

88 "cette renaissance de Rosélie en femme cannibale est motivée par une perte de sens totale et douloureuse, une tabula rasa existentielle dans laquelle elle puise un nouveau pouvoir créateur symbolisé en particulier par le fait qu'elle est capable de nommer son tableau (alors que d'habitude elle n'arrive pas à trouver de titres pour ses peintures)"

89 "Si tu ne peins plus, tu ne vis plus. Quand reviendras-tu vers nous ?"

90 "There is a strong tradition of what is called literary cannibalism in the Caribbean"

${ }^{91}$ Suzanne Césaire (1915-1966), professora, escritora e militante martinicana, foi esposa de Aimé Césaire, com tem teve seis filhos. Suzanne e Aimé trabalharam de forma colaborativa em revistas e no movimento da Négritude desde que se conheceram em Paris, durante os estudos superiores. Durante a Segunda Guerra Mundial, Suzanne funda com outros escritores a revista Tropiques e precisa resistir à perseguição e à censura do governo francês. Um dos mais importantes artigos de sua autoria Le Grand camouflage, de 1945, preconiza a importância de uma postura nacional e decolonial capaz de fazer com que antilhanos abandonem a camuflagem europeia, branca e elitista que insistiam em vestir. Trata-se de uma líder intelectual que se dedicou a fomentar a literatura nacional martinicana.

92 "On the eve of World War II, Suzanne Cesaire, in the journal Tropiques, uttered her famous command: 'Martinican poetry shall be cannibalistic or shall not be"' 
(1993, p.122). O lema foi evocado pelo poeta martinicano René Menil, co-fundador de Tropiques: "Uma literatura se forma. (...) A poesia martinicana será viril. A poesia martinicana será canibal. Ou não será"93 (MENIL, 2015, p. 109). Neste contexto,

essa identidade 'canibal' reivindicada por Suzanne Césaire e outros escritores antilhanos, e que Rosélie também afirma, não é, portanto, uma identidade forjada de forma passiva, devorada e digerida por outros, mas se alimenta ao contrário ativamente de 'outras' culturas ${ }^{94}$ (MIGRAINEGEORGES, 2010, p. 515).

Aprofundando a análise, a pesquisadora francesa Maria-Agnès Sourieau explica:

Na minha opinião, é isso que Suzanne Césaire está buscando ao inserir o canibalismo na poesia martinicana: quer tanto descolonizar a influência cultural francesa quanto estabelecê-la na sua ordem cultural. Essa descolonização da escrita sugere, por um lado, que será operada com violência e ferocidade, como vingança 'justa' contra a absorção forçada de séculos de uma cultura estrangeira. Trata-se de devolver ao inimigo sua própria ideologia. Mas, por outro lado, se a ingestão 'canibal' da poesia martinicana indica o envolvimento da cultura francesa, há uma inevitável assimilação de alguns de seus elementos, incluindo a linguagem. Uma vez digerida e transformada, ela necessariamente nutrirá a Poesia Martinicana ${ }^{95}$ (1994, p.73-74).

Em Histoire à la femme cannibale há diversas citações a autores e obras, sobretudo antilhanas. O canibalismo literário que cita fontes e alude ao aglutinado de textos que se espelham, se inspiram e se (retro)alimentam. Césaire, Fanon, Simone Schwarz-Bart, René Depestre, Joseph Zobel, Agatha Christie, Chester Himes se tornam exemplos de obras devoradas por Maryse Condé e recosidas na tessitura de seu romance. O procedimento de acumulação se mostra recorrente em obras antilhanas: acolher referências culturais, identificar o caminho intelectual percorrido, homenagear baluartes e antecessores. O texto assume a

\footnotetext{
93 “Une littérature se forme. (...) La poésie martiniquaise sera virile. La poésie martiniquaise sera cannibale ou ne sera pas"

94 “'Cette identité 'cannibale' que réclament Suzanne Césaire et d'autres écrivains antillais, et que revendique également Rosélie, n'est donc pas une identité passivement façonnée, dévorée et digérée par les autres mais elle se nourrit au contraire activement des 'autres' cultures"

95 "C'est, à mon sens, ce que vise Suzanne Césaire en inscrivant le cannibalisme dans la poésie martiniquaise: elle veut tout à la fois la décoloniser de l'emprise culturelle française et l'établir dans l'ordre culturel qui est sien. Or cette décolonisation de l'écriture suggère, d'une part, qu'elle sera opérée avec violence et férocité, comme une 'juste' revanche contre l'absorption forcée séculaire d'une culture étrangère. Il s'agit de retourner contre l'ennemi sa propre idéologie. Mais, d'autre part, si l'ingestion 'cannibale' par la poésie martiniquaise indique l'engloutissement de la culture française, il s'opère une assimilation inévitable de certains de ses éléments, dont la langue. Celle-ci, une fois digérée et transformée, va nécessairement nourrir la poésie martiniquaise”
} 
pluralidade e o mosaico que caracterizam o Caribe, espaço de encontros e crioulizações ${ }^{96}$. A escrita se assume como ato coletivo no que pese a singularidade de cada autor e o trabalho individual de produção. O compromisso repousa na construção de um inventário referencial e plural capaz de abarcar as especificidades caribenhas.

Em entrevista, Condé explica de maneira singela o fenômeno basilar do canibalismo artístico: "tenho um amigo que é um haitiano e um músico conhecido. Seu último disco foi uma espécie de música brasileira. Por que não? Temos que pegar emprestado. Fiz a mesma coisa - peguei emprestado a ideia de Emily Brontë, que, afinal, é uma escritora branca"97 (WOLFF, 1999). E a partir do axioma do empréstimo, que atenua a violência essencial do termo canibalismo, a autora nos permite propor outros canibalismos: a reescritura de obras, o canibalismo pictórico entre os quadros ensanguentados e mutilados de Michel Rovélas e Rosélie e, por fim, o canibalismo entre mãe e pai cujos nomes se coadunam para compor o nome de Rosélie.

Por fim, para insistir um pouco mais na reescritura de obras como vertente do canibalismo, podemos apontar para o fato de Condé ter escrito em 1995 La Migration des cœurs, que retoma o enredo de Wuthering Heights de Emily Brontë, de 1990. Condé se dedicou a outro canibalismo literário quando redigiu La Belle et la Bête: une version guadeloupéenne (2013), a partir do clássico de Le prince de Beaumont. Um e outro caso se assemelham na inscrição da realidade crioula nas novas versões, ambientados no Caribe e inscritos na cultura local. Assim, Condé se apropria de clássicos para neles imprimir as artes de dizer e de fazer das Antilhas, suas vestimentas, sua gastronomia, suas paisagens, seus dilemas. O canibalismo, assim, opera o lúdico ao mesmo tempo em que desnaturaliza as narrativas europeias, fragilizando as hierarquias e ressignificando o cânone. Condé promove, igualmente, um canibalismo de si mesma quando adapta em versão infanto-juvenil romances adultos de sua autoria. É o que ocorre com alguns capítulos de Ségou - Les murailles de terre, de 1984, recriados em Chiens fous dans la brousse, de $2006^{98}$. E o que dizer de personagens

\footnotetext{
96 Termo cunhado pelo escritor e ensaísta martinicano Édouard Glissant (1928-2011) que, em breves palavras, observa o fenômeno da imprevisibilidade do mundo advinda do contato de diversas culturas e identidades em relação. Sobre este tema, ver as seguintes obras de Glissant: Poétique de la Relation, (1990), Introduction à une Póetique du divers (1995; A edição brasileira, traduzida por Enilce do Carmo Albergaria Rocha e publicada em 2005, se intitula Introdução a uma poética da diversidade) e Traité du Tout-Monde (1997).

97 "I have a friend who is a Haitian and a well-known musician. His last record was a kind of Brazilian music. Why not? We have to borrow. I did the same thing-I borrowed the idea from Emily Brontë, who, after all, is a white writer"

98 A este respeito, ver o artigo "Contar a história da colonização e da escravidão para as crianças: a literatura infanto-juvenil pós-colonial de Maryse Condé e Gisèle Pineau", de Pauline Franchini, In BATALHA, Maria Cristina \&. ROCHA, Vanessa Massoni da (Orgs.). Literatura, história e pós-colonialidade: vozes em diálogo. Rio de Janeiro: Dialogarts, 2019, p. 205-236.
} 
que transitam entre obras literárias diversas, convocando o leitor a erigir paralelos de leitura e cerzindo um universo literário em diálogo? Citemos o exemplo do personagem Carmélien, de Maryse Condé, que aparece em Traversée de la mangrove (1989) e em La Belle et la Bête : une version guadeloupéenne? (2013)

Estas ponderações nos encaminham para a aproximação dos termos Canibal e Caliban, este último personagem da peça Tempestade, de Skakespeare, escrita no século XVII. O nome de Caliban, escravo negro de Próspero, seria um anagrama de Canibal. A relação dos personagens Caliban/Próspero se torna uma alegoria da relação entre colonizados e colonos, entre poder e subjugação, na qual Caliban personificaria os oprimidos e alijados. Aimé Césaire realiza em 1969 uma adaptação da peça para o teatro negro. Na versão césairiana, Caliban se faz ressaltar por ter sido o chefe da ilha antes da chegada de Próspero com a filha Miranda. É a história de dominação colonial que passa a ser revisitada, valorizando a resistência de Caliban que rejeita, inclusive, a imposição deste nome.

Para concluir, à luz da pós-colonialidade, impõe-se a premissa de Césaire que ressignifica o discurso civilizatório europeu e inscreve novas versões que concedem a Caliban o protagonismo rasurado e silenciado até então, mudando o foco da narrativa. Nesta perspectiva, pensar em canibalismo nas Antilhas francesas consiste em subverter paradigmas consolidados numa ótica decolonial, revisionista e descomprometida com o cânone europeu. Fiéla, a mulher canibal que inspira Rosélie, ousa assassinar o marido provedor em uma sociedade patriarcal e escandaliza a opinião pública. Ela transforma o antigo companheiro, como acusa a polícia, em alimento que foi caçado, abatido, vencido. Presa, ela não chora, não clama por piedade nem se esmera em se defender. Ela se comporta à revelia das leis e dos protocolos de punição que lhe são infligidos. Na cadeia, retira sua vida quando assim o deseja, escapando da longa pena de encarceramento que lhe foi atribuída. Sua foto no jornal, a força do seu olhar e sua trajetória corajosa inspiram Rosélie, guiando-a ao retorno à pintura e à vida. Há na narrativa um jogo de cumplicidade entre mulheres que sofrem e que buscam maneiras de sobrepor suas dores e mazelas, a despeito da presença de homens abusivos. Maryse Condé coloca em cena a autorrepresentação feminina e insiste na importância dos olhos, como metáfora de ver e do ser visto, valorizando a supremacia da visão em 'terra de cegos'. 


\section{REFERÊNCIAS}

20 MINUTES SOCIÉTÉ. "Négrophobie d'Etat" : La statue de Colbert devant l'Assemblée nationale vandalisée. https://www.20minutes.fr/societe/2806495-20200624-racisme-statuecolbert-devant-assemblee-nationale-vandalisee, 2020.

ADENET-LOUVET, Marjory. Interview à Richard Philcox. Potomitan, https: //www.potomitan.info/conde/philcox.php, 2007.

ADICHIE, Chimamanda Ngozi. O perigo de uma única história. São Paulo: Companhia das letras, 2019.

ALI-BENALI, Zineb e SIMASOTCHI-BRONÈS, Françoise. Le rire créole: entretien avec Maryse Condé. Revue Littérature n 154, 2009, p. 13-23.

ALMEIDA, Maria Cândida Ferreira de. Só me interessa o que não é meu: a antropofagia de Oswald de Andrade. Relea - Comisión de Estudios de Postgrado de la Facultad de Economía. Universidad Central de Venezuela, Caracas, v. 14, 2001, p. 93-121.

ANDRADE, Oswald de. Manifesto antropofágico. https://www.zonacurva.com.br/omanifesto-antropofagico-de-oswald-de-andrade/

ANDRADE, Oswald de. Obras completas. In BOAVENTURA, Maria Eugênia (org.). Estética e política. São Paulo: Globo, 1992.

BEAUMONT, Olivier. Allocution de Macron : cette mémoire coloniale qui embarrasse le président. Le Parisien. https://www.leparisien.fr/ politique/allocution-de-macron-cettememoire-coloniale-qui-embarrasse-le-president-15-06-2020-8336145.php, 2020. Consultado em 20 de julho de 2020.

BERRY, Anne-Catherine. Le corps archipélique dans les arts plastiques des Antilles françaises. Tese de doutorado de Artes plásticas. Université des Antilles, Martinique, 2017. http://www.theses.fr/2017ANTI0174/abes. Consultado em 12 de julho de 2020.

CAVAGNOLI, Ana Carolina. "Atravessando o mangue com Maryse Condé: a crise entre assimilação, ventriloquia, resistência e liberdade. E-cadernos CES n. 14, 2011, p.134-164.

CHAMOISEAU, Patrick. Écrire en pays dominé. Paris: Éditions Gallimard, 2011.

CHERKI, Alice. Préface à l'édition 2002. In FANON, Frantz. Les damnés de la terre. Paris: Éditions La Découverte \& Syron, 2002, p.5-15.

CONDÉ, Maryse. “Order, Disorder, Freedom, and the West Indian Writer", Yale French Studies, 83.2, 1993, p. 121-135.

CONDÉ, Maryse. Histoire de la femme cannibale. Paris: Mercure de France, 2012.

EVARISTO, Conceição. Prefácio - Tituba, um evocar das águas que ainda nos atormenta! In CONDÉ, Maryse. Eu, Tituba: Bruxa negra de Salém. Tradução de Natália Borges Polesso. Rio de Janeiro: Rosa dos Tempos, 2019, p. 7-13. 
FIGUEIREDO, Eurídice. Construções de identidades pós-coloniais na literatura antilhana. Niterói: EdUFF, 1998.

FRANCHINI, Pauline. "Contar a história da colonização e da escravidão para as crianças: a literatura infanto-juvenil pós-colonial de Maryse Condé e Gisèle Pineau", de Pauline, In: BATALHA, Maria Cristina \&. ROCHA, Vanessa Massoni da (Orgs.). Literatura, história e pós-colonialidade: vozes em diálogo. Rio de Janeiro: Dialogarts, 2019, p. 205-236.

GLISSANT, Édouard. Introduction à une poétique du divers. Paris: Gallimard, 1996.

KILANI, Mondher. Le cannibalisme - une catégorie bonne à penser. L'Esprit du temps. No 129, 2006, p. 33-46.

LARCHER, Laurent. Maryse Condé, écrire et ne rien ceder. La croix. https://www.la-croix. com/Culture/Maryse-Conde-ecrire-rien-ceder-2019-09-14-1201047474, 2019. Consultado em 23 de agosto de 2020.

LÖWY, Michael (2011). "A contrapelo". A concepção dialética da cultura nas teses de Walter Benjamin (1940). In Revista Lutas Sociais, São Paulo, n.25/26, p.20-28.

MENIL, René. Laissez passer la poésie In CÉSAIRE, Suzanne. Le grand camouflage. Écrits de dissidence (1941-1945). Paris: SEUIL, 2015, p. 107-109.

MIGRAINE-GEORGES, Thérèse. De Traversée de la mangrove à Histoire de la femme cannibale: L'art comme arme miraculeuse chez Maryse Condé. Romanic Review 101, no. 3, 2010, p.499-521.

NOËL, James. Kana Sutra In AMARAL, Henrique Provinzano (org.). Estilhaços - Antologia de Poresia haitiana contemporânea. São Paulo: Demônio Negro, 2020, p. 66-69.

PFAFF, Françoise. Entretiens avec Maryse Condé. Paris: Karthala, 1993.

RIBEIRO, Ribeiro. Quem tem medo do feminismo negro? São Paulo: Companhia das Letras, 2018.

RIOS, Flávia. Por um feminismo radical. In VERGÈS, Françoise. Feminismo decolonial. Tradução de Jamille Pinheiro Dias e Raquel Camargo. São Paulo: Ubu Editora, 2020, p. 7-11.

SCHELCHER, Victor. Esclavage et colonisation. Paris: Presses Universitaires de France, 2008.

SOURIEAU, Marie-Agnès. "Suzanne Césaire et Tropiques: de la poésie cannibale à une poétique créole". The French Review, 68.1, 1994, pp. 69-78.

TREMBLAY, Emmanuelle. Portrait d'une solitude / Histoire de la femme cannibale, de Maryse Condé, Mercure de France, 316 p. Spirale, (197), 2004, p.55-56.

VERGÈS, Françoise. Feminismo decolonial. Tradução de Jamille Pinheiro Dias e Raquel Camargo. São Paulo: Ubu Editora, 2020. 
VIALA, Fabienne. Transgression et barbárie dans les destinées féminines romanesques de Maryse Condé. In CARRUGGI, Noëlle (org.). Maryse Condé - Rébellion et transgressions. Paris: Karthala, 2010, p. 131, 146.

WOLFF, Rebecca. Maryse Condé by Rebecca Wolff. Boom. https://bombmagazine.org/ articles/maryse-cond\%C3\%A9/, 1999. Consultado em 15 de outubro de 2020.

Recebido: $24 / 09 / 2020$

Aprovado: 12/02/2021 